surrender values; reducing our competitive performance by holding back reserves; and were likely to produce serious problems of inequity and even losses if there was a deterioration in the equity market. The current taxation structure of life business was likely to put it in an uncompetitive position compared to other financial competitors for long-term business.

\title{
FINAL PAY PENSION SCHEMES-DEFERRED PAY OR COMPANY PROVIDED BENEFIT?
}

\author{
By A. R. Escolme
}

(Synopsis of a paper presented to the Society on 3 February 1987)

THE paper is concerned solely with funded pension schemes of the final or final average salary type. The following is a brief summary of the arguments and conclusions it contains.

There are two extreme or 'pure' types of final pay scheme, which I call Deferred Pay and Company Benefit Schemes.

Generally, employers (and employees, journalists and politicians) are unaware of the distinctions between the two types of scheme. Consequently many employers with final pay schemes have not considered which type of scheme, or just what compromise between the two, they want to operate.

This gives rise to some confusion of thought and action which in turn causes and has caused conflict with scheme members and their representatives. (The lack of recognition of the two types of scheme may also have given rise to some confusion of thought among accountants, journalists and politicians.)

Actuaries and other pension scheme practitioners would render a service to their corporate clients if they led clients to consider the two types of scheme in their extreme or pure form, the advantages and disadvantages of each and the client's preferences having regard to corporate personnel and financial policies.

In practical terms it might not be possible, or in some instances it might be undesirable, for the client to transform his existing final pay scheme into one or other the two extreme forms. Nevertheless, a consideration of the two types of scheme could well result in clearer objective setting by the employer in relation to this scheme and in particular to the setting of clearer communications objectives, with a resulting reduction in potential misunderstanding and conflict.

The paper contains a number of examples of conflict and confusion of thought which have arisen with final pay schemes. The examples provide a context for the 
detailed definition of the two types of final salary scheme which is done by reference to 15 key points applicable to final pay schemes.

The author believes that thinking about final pay schemes in these ways leads to useful conclusions about such things as how the employer should communicate the schemes to members, accounting for pension costs in company accounts and the issues involved in mergers and take-overs.

\section{THE EXPANDING UNIVERSE}

\section{BY A. J. Frost}

(Synopsis of a paper presented to the Society on 17 February 1987)

IN February 1987 I led a discussion at a meeting of the Staple Inn Actuarial Society on 'The Expanding Universe'. This was an oblique reference to the Big Bang that had engulfed the City and on which I had written intermittently since late 1985. After referring briefly to the history leading to the changes I wrote some thoughts on the new groupings in the City, the conflicts likely to arise, the changes in practice, the changes to remuneration of the various parties, the technological requirements, and the growing internationalization of the financial market place. On each occasion that I have written, events have occurred afterwards with bewildering speed. In a synopsis such as this (written in July 1987 ) it would be fruitless to attempt to summarize developments in any detail.

Even now the rule books of the new regulatory bodies such as LAUTRO, IMRO and FIMBRA are being written. These organizations, and their rule books, are the product of a revolution in the financial services market which has been proceeding in parallel with changes to the Stock Exchange. The latter has transmogrified during the past few years in seeking to retain its position on the world financial stage. The consequence of the changes to its own code of practice is manifested in the new conglomerates now scattered across London--no longer just the City of London. A number of players have, however, already withdrawn from gilt and equity market making. Foreign ownership and access to a greater capital base seems to be the end result for a number of traditionally British niche businesses.

One of the new roles to emerge as a result of the legislation has been that of the compliance officer. There has been need of them already. Let us hope the expanding universe of players and products does not produce a steady stream of causes célèbres. Changes in practice have been extensive and no more so than in the gilt market where the basis of issuing stock has been enlarged to include an auction system. Pressures on costs have become apparent in the new groupings as expected which help to explain the scaling down of several operations established within the last year. 